\title{
A Mixed Infection of Lettuce chlorosis virus, Papaya ringspot virus, and Tomato yellow leaf curl virus-IL Detected in a Texas Papaya Orchard Affected by a Virus-Like Disease Outbreak
}

Olufemi J. Alabi, Department of Plant Pathology \& Microbiology, Texas A\&M AgriLife Research and Extension Center, Weslaco, TX; M. Al Rwahnih, Department of Plant Pathology, University of California, Davis, CA; J. L. Jifon, Department of Horticultural Sciences, Texas A\&M AgriLife Research and Extension Center, Weslaco, TX; M. Sétamou, Department of Agriculture, Agribusiness, and Environmental Sciences, Texas A\&M University, Kingsville Citrus Center, Weslaco, TX; J. K. Brown, School of Plant Sciences, University of Arizona, Tucson, AZ; L. Gregg, Texas A\&M AgriLife Research \& Extension Center, Weslaco, TX; and J.-W. Park, Texas A\&M University, Kingsville Citrus Center, Weslaco, TX

\begin{abstract}
Severe virus-like symptoms consisting of mosaic, distortion, yellowing, and brittleness were observed on papaya plants in a 20-ha orchard in South Texas during the 2014-15 growing season. Incidence of symptomatic plants increased from 40 to $100 \%$ within 6 months of the outbreak; the most severely affected plants were stunted, and fruit yield and quality were reduced compared with asymptomatic plants. The orchard papaya plant virome was explored using the Illumina NextSeq 500 platform and results were validated by Sanger DNA sequencing of complete viral genomes obtained by PCR amplification. The combined results revealed the presence of Papaya ringspot virus (PRSV; Potyvirus), Lettuce chlorosis virus (LCV; Crinivirus), and Tomato yellow leaf curl virus-IL (TYLCV-IL; Begomovirus). The RT-PCR analyses of leaves from 51 randomly sampled

papaya plants indicated the presence of PRSV, LCV, and TYLCV-IL in $100,39.2$, and $15.7 \%$ of the samples, respectively. Plants infected with PRSV, in combination with LCV and/or TYLCV-IL, exhibited more severe symptoms compared with plants infected with PRSV alone. Furthermore, successful whitefly-mediated transmission of TYLCV-IL and LCV was accomplished by exposing virus-free papaya seedlings to viruliferous Bemisia tabaci (Genn.) under greenhouse conditions. The results of this study document a new host record for LCV and the first successful whitefly-mediated transmission of TYLCV-IL and LCV to papaya. As a perennial crop, infected papaya serving as an over-seasoning reservoir for TYLCV-IL and LCV, presents a new challenge to viral disease management in papaya orchards.
\end{abstract}

Papaya (Carica papaya L.), a plant native to the south of Mexico and Central America (Fuentes and Santamaria 2014), is cultivated widely in tropical and subtropical regions of the world primarily for its edible fruit often consumed fresh or processed into juice. The green fruit of papaya is also used in salad in many countries of Southeast Asia and papain, an enzyme extract derived from its latex exudates, is widely used as a meat tenderizer. The Food and Agriculture Organization crop production statistics estimate papaya production at 11.6 million metric tons of fruits in 2014 (FAOSTAT 2016). From highest to lowest, India (44\%), Brazil (12.5\%), Nigeria (6.6\%), Indonesia (6.6\%), Mexico (6.5\%), and the Dominican Republic (5.5\%), accounted for $\sim 82 \%$ of the world's production (FAOSTAT 2016). In the U.S., Hawaii accounts for most of the domestic papaya crop. However, papayas can be produced commercially in coastal and southern parts of Texas afforded natural protection from severe weather conditions. Consequently, growers in the Lower Rio Grande Valley area of South Texas have invested in papaya production to meet local demands for the fruit by an increasingly culturally diverse populace. This "new" crop faces several potential production limitations including biotic and abiotic stresses such as virus diseases.

Compared with many other crop species, plant viruses belonging to only a few genera have been reported to infect papaya. Among these are Papaya ringspot virus (PRSV) and Papaya leaf distortion mosaic virus (PLDMV) (genus Potyvirus; family Potyviridae), Papaya mosaic virus (genus Potexvirus; family Alphaflexiviridae), Papaya meleira virus and Papaya lethal yellowing virus (genus Sobemovirus),

Corresponding author: Olufemi J. Alabi; E-mail: alabi@tamu.edu

*The $\boldsymbol{e}$-Xtra logo stands for "electronic extra" and indicates that five supplementary figures are available online.

Accepted for publication 6 March 2017.

C 2017 The American Phytopathological Society several begomoviruses (family Geminiviridae), and Tomato spotted wilt virus (genus Tospovirus; family Bunyaviridae).

The most widespread and economically important is PRSV, ubiquitous in papaya-producing regions of the world. Historically, PRSV outbreaks have been reported in papaya and cucurbits (Fermin and Gonsalves 2003; Gonsalves 1998). The flexuous, filamentous particle of PRSV encodes a single stranded, positive sense, 10,326 nt long RNA that is processed into a large polyprotein subsequently cleaved into functional proteins by virus-encoded proteases (Purcifull et al 1984; Yeh et al. 1992). PRSV is mainly transmitted in a nonpersistent manner by several aphid species (Kalleshwaraswamy and Krishna Kumar 2008; Purcifull et al. 1984), and by seed (Bayot et al. 1990), although the latter mode of transmission is considered insignificant (Fermin and Gonsalves 2003). Two strains of the virus, PRSV-P and PRSV-W, have been recognized based on natural host range. Both strains can infect species in Cucurbitaceae but only PRSV-P occurs naturally in papaya (Gonsalves 1998; Purcifull et al. 1984). Recently, Tomato yellow leaf curl virus-Israel (TYLCV-IL, Begomovirus) was reported infecting papaya plants (Alabi et al. 2016), a result that points to a wider than expected host range for this whitefly-transmitted virus, notable primarily for the damage it causes to tomato and certain other cultivated plants (Díaz-Pendón et al. 2010). To date, no member of the genus Crinivirus (family Closteroviridae) (Martelli et al. 2011) has been reported to infect papaya under natural or experimental conditions.

Insect vector-transmitted viruses that cause disease in cultivated or wild annual and perennial plants present challenges to disease management because they can serve as virus reservoirs and drivers of virus evolution. An increased understanding of the ecology of these viruses is expected to provide insights into epidemiological factors that could enhance disease management practices. In this study, diverse types of whitefly-transmitted plant viruses were associated for the first time with severe mosaic symptoms in a papaya orchard in South Texas, U.S.A. Using high throughput sequencing for discovery, together with Sanger DNA sequencing of amplified, cloned viral genomes, the identity and association of three viruses, Lettuce chlorosis virus (LCV; genus Crinivirus), TYLCV-IL, and PRSV 
with symptomatic, infected papaya plants in South Texas were determined. Also, experimental whitefly-mediated transmission was demonstrated for LCV and TYLCV-IL between infected and virus-free papaya plants.

\section{Materials and Methods}

Field assessment and provenance of the sample. The study was conducted at a 20-ha papaya orchard located in Hidalgo County of the Lower Rio Grande Valley, Texas $\left(46.2^{\circ} \mathrm{N}, 119.8^{\circ} \mathrm{W}\right)$ planted to $\mathrm{cv}$. Red Maradol. The orchard was established during spring 2014 and maintained by the grower using standard horticultural practices. During fall 2014, leaves on some papaya trees developed virus-like symptoms that consisted of severe mosaic, leaf distortion, vein-clearing, yellowing, leaf brittleness, or a combination thereof (Fig. 1). The hallmark ringspot symptom commonly associated with PRSV infection (Fermin et al. 2015) was observed on unripened, green fruit of some of the papaya trees (Fig. 1D). Green peach aphids Myzus persicae (Sulzer) and adult whiteflies of the Bemisia tabaci (Gennadius) sibling species group (Brown 2010) were observed feeding and reproducing on papaya plants. The disease incidence and spatial distribution patterns were assessed and recorded for a four-row block in the middle of the orchard. Also recorded were yield, plant height, and number of fruit per tree. Leaf samples were collected from four symptomatic and four asymptomatic plants growing adjacent to one another in the orchard. Care was taken to ensure that the four symptomatic plants represented the spectrum of observed field symptoms. All leaf tissue samples were immediately frozen in liquid $\mathrm{N}_{2}$ and stored at $-80^{\circ} \mathrm{C}$ until further analysis.

RNA isolation, quality control, cDNA library preparation, and sequencing. Total RNA was extracted from leaf samples using the RNeasy Plant Mini Kit (Qiagen, Valencia, CA) according to manufacturer's instructions. The RNA was treated with DNAse I (Qiagen) and the concentrations determined using a Nanodrop ND1000 spectrophotometer (NanoDrop Technologies, Rockland, DE). The RNA concentrations were measured when the $\mathrm{A}_{260} / \mathrm{A}_{280}$ ratio ranged from 1.8 to 2.2. An equal amount of RNA from subsets obtained from the same collection was pooled to obtain three subsamples. Samples for library preparation consisted of one subsample from the four nonsymptomatic plants (PMcA-H), and two subsamples from pairs of symptomatic plants (PMcA-D1 and PMcA-D2) The subsamples were subjected to quality analysis using the Experion Automated Electrophoresis System (Bio-Rad Laboratories, Inc., Hercules, CA), yielding acceptable RNA quality indicator (RQI) and ratio [28S/18S] values (Supplementary Fig. S1). The ribosomal (r)RNA was removed using the Ribo-Zero rRNA Removal Reagents v2 (Plant Leaf)-Low Input (Epicenter, Madison, WI), according to the manufacturer's instructions. Complementary DNA (cDNA) libraries were prepared using the ScriptSeq v2 RNA-Seq Library Preparation Kit (Epicenter), according to the manufacturer's instructions. The cDNA libraries were subjected to high-throughput sequencing (HTS) at the University of Southern California Sequencing Facility using the Illumina NextSeq 500 platform. Bioinformatics analyses of the generated sequence reads were performed as described previously (Al Rwahnih et al. 2016).

Validation of HTS results via RT-PCR, cloning, and complete genome sequencing. To validate the results of HTS, pairs of virusspecific primers (Table 1) were designed for each virus species recovered, and used to amplify a complete genome for each as overlapping DNA fragments. For PRSV and LCV, a cDNA template was produced from the total RNA isolated from two field samples using random hexamers and the ThermoScriptT RT-PCR Systems (Life Technologies, Carlsbad, CA). The cDNA was subjected to PCR with virus-specific primers to produce overlapping DNA amplicons (Table 1). The $5^{\prime}$ and $3^{\prime}$ ends sequences were determined using the Clontech SMARTer RACE 5'/3' kit (Clontech Laboratories Inc., Mountain View, CA), per manufacturer's instructions.

For TYLCV-IL, total DNA from three samples was used as templates for rolling cycle amplification (RCA), carried out with the TempliPhi 100 Amplification Kit (GE Healthcare Biosciences Corp., Cranbury, NJ). The RCA template was subjected to PCR amplification using two different pairs of abutting primers, based on the HTS sequences (Table 1) (Alabi et al. 2016). The PCR reactions were carried out in a $25 \mu \mathrm{l}$ reaction volume using the PrimeSTAR GXL DNA Polymerase (Clontech Laboratories, Inc.), according to the manufacturer's recommendations.

For the RNA viruses, PCR cycling used touchdown PCR consisting of an initial denaturation step at $95^{\circ} \mathrm{C}$ for $5 \mathrm{~min}$, followed by 15 cycles for denaturation: $94^{\circ} \mathrm{C}$ for $30 \mathrm{~s}$; annealing: $68^{\circ} \mathrm{C}$ or $65^{\circ} \mathrm{C}$ for $30 \mathrm{~s}\left(1^{\circ} \mathrm{C}\right.$ decrease per cycle; extension: $72^{\circ} \mathrm{C}$ for $1 \mathrm{~kb}$ per min rate), followed by 25 cycles at $53^{\circ} \mathrm{C}$ or $50^{\circ} \mathrm{C}$ annealing, respectively (Table 1). The TYLCV-IL sample was subjected to PCR using the PrimeSTAR GXL DNA Polymerase Rapid PCR Protocol (Clontech Laboratories, Inc.). Cycling was performed in a S1000TM Thermal Cycler (BioRad Laboratories, Inc., Hercules, CA). The presence and expected size of each PCR amplicon was examined by electrophoresis in $1 \%$ agarose gel prestained with ethidium bromide, in TAE buffer pH 8.0, using a $1 \mathrm{~Kb}$ Plus DNA ladder (Life Technologies). The expected size DNA band was eluted from the gel (ZymocleanTM Gel DNA Recovery Kit, Zymo Research Corp., Irvine, CA), A-tailed, and cloned into pCR2.1 TOPO-TA vector (Life Technologies). Plasmid DNA isolated from three clones per amplicon (GenElute, SigmaAldrich Corp., St. Louis, MO) were subjected to bidirectional Sanger DNA sequencing. A consensus sequence for three clones per virus, and the putative full-length viral genome assemblies, were obtained using BioEdit (Hall 1999). Sequence annotations and open reading frame (ORF) predictions were performed using the SnapGene Viewer 2.8.2 software (GSL Biotech; snapgene.com). Multiple sequence alignment of the nucleotide (nt) and amino acid (aa) sequences were performed using the MUSCLE program (Edgar 2004), implemented in the Analysis Tool Web Services from the EMBL-EBI site (McWilliam et al. 2013). Aligned sequences were used to determine phylogenetic relationships (Kumar et al. 2016) and percent nucleotide identity between
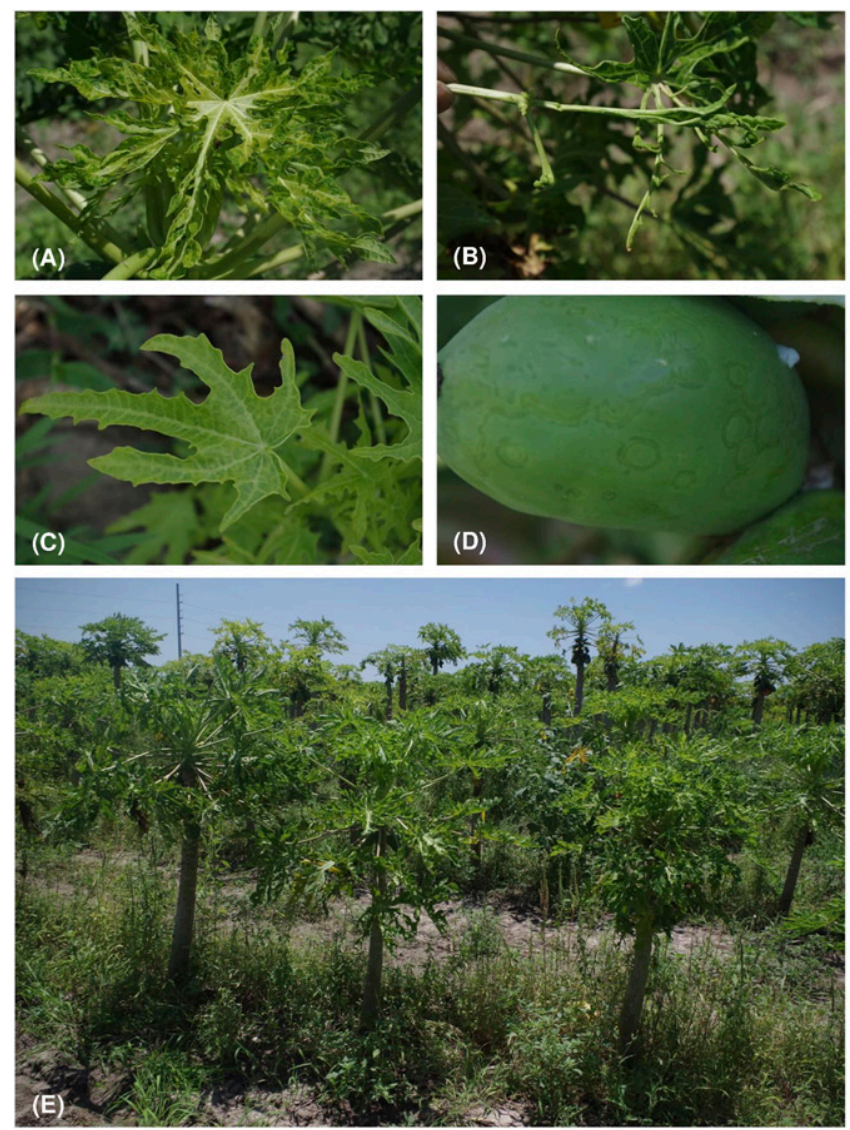

Fig. 1. Disease symptoms observed on papaya plants in a Texas orchard. The symptoms consisted of severe mosaic $(\mathbf{A})$, leaf distortion $(\mathbf{B})$, vein-clearing and leaf brittleness $(\mathbf{C})$, and yellowing ( $\mathbf{A}$ and $\mathbf{C}$ ). Ringspot blemishes were also observed on the surface of fruits (D). Papaya trees in the orchard showed different combinations of these symptom types (E). 
sequences for each viral species (Hall 1999). Graphical representations of genome-wide sequence comparisons were made with Simplot v3.5.1 (Lole et al. 1999), and selected reference isolate sequences obtained from the GenBank database were included in the analysis for each virus.

RT-PCR screening of field samples. The percent detection of PRSV, LCV, and TYLCV-IL, and frequency of occurrence as a single or mixed infection in the papaya orchard, was determined by RTPCR amplification from purified RNA or DNA isolated from leaves of 51 field-infected, symptomatic papaya plants. Three pairs of virusspecific diagnostic primers were designed and used for detection of
PRSV (PRSV-F1 [nt1616] and PRSV-R4 [nt2899]; expected size $\sim 1.2 \mathrm{kbp}$ ), LCV (LCV-50 and LCV-25; expected size $482 \mathrm{bp})$, and TYLCV (V1701 and C515; expected size $~ 1.7 \mathrm{kbp}$ ) (Idris and Brown 1998) (Table 1). The amplicons were cloned and the DNA sequence determined using Sanger sequencing, with assembly and analyses, as described above. A log-likelihood ratio test was used to compare the proportion of plants infected by each virus using the PROC FREQ of SAS (SAS Institute 2008).

Whitefly transmission. Six symptomatic papaya plants that tested positive for various combinations of HTS-detected viruses were

Table 1. Primers and PCR conditions used for the amplification of complete genomes of isolate PTX of Papaya ringspot virus (PRSV), Lettuce chlorosis virus (LCV), and Tomato yellow leaf curl virus-Israel (TYLCV-IL) as overlapping DNA fragments and their expected product sizes

\begin{tabular}{|c|c|c|c|c|c|}
\hline \multirow[b]{2}{*}{ Primer name $^{\mathbf{a}}$} & \multirow[b]{2}{*}{ Sequence $\left(5^{\prime}-3^{\prime}\right)$} & \multicolumn{2}{|c|}{ Annealing temperature ${ }^{\mathbf{b}}$} & \multirow[b]{2}{*}{ (bp) } & \multirow[b]{2}{*}{ Target } \\
\hline & & Cycle 1 & Cycle 2 & & \\
\hline PRSV 5' end (nt1) & AAATAAAACATCTCAACACAACATAATCAAAAGC & & & & \\
\hline PRSV-R1 (nt1670) & GCTTACCTTCAAGACGTCCTCGGACAACG & $\begin{array}{c}68^{\circ} \mathrm{C}\left(-1^{\circ} \mathrm{C} / \text { cycle }\right. \\
\text { for } 15 \text { cycles })\end{array}$ & $53^{\circ} \mathrm{C}(25$ cycles $)$ & 1,670 & PRSV \\
\hline PRSV-F1 (nt1616) & GTGGGGCGATATTTTGGTGATTATTTCGTTG & & & & \\
\hline PRSV-R4 (nt2899) ${ }^{\mathrm{c}}$ & CAGCTGATTTGCGCATGTTGCGACATC & $\begin{array}{c}68^{\circ} \mathrm{C}\left(-1^{\circ} \mathrm{C} / \text { cycle }\right. \\
\text { for } 15 \text { cycles })\end{array}$ & $53^{\circ} \mathrm{C}(25$ cycles $)$ & 1,283 & PRSV \\
\hline PRSV-F3 (nt2666) & ATCGTTCTTGGTAATTCTGGTGATCC & & & & \\
\hline PRSV-R6 (nt6653) & CTTGCACCATTGAAATATCAGTCTGTGG & $\begin{array}{c}68^{\circ} \mathrm{C}\left(-1^{\circ} \mathrm{C} / \text { cycle }\right. \\
\text { for } 15 \text { cycles })\end{array}$ & $53^{\circ} \mathrm{C}(25$ cycles $)$ & 3,787 & PRSV \\
\hline PRSV-F5 (nt6495) & AGAAAGGAAAGATGCATGGCATG & & & & \\
\hline PRSV-R8 (nt9087) & CTTAATCCAACTTCTGAGACGTATG & $\begin{array}{c}65^{\circ} \mathrm{C}\left(-1^{\circ} \mathrm{C} / \text { cycle }\right. \\
\text { for } 15 \text { cycles })\end{array}$ & $50^{\circ} \mathrm{C}(25$ cycles $)$ & 2,592 & PRSV \\
\hline PRSV-F8 (nt9034) & CAATGAGTTGGCGAAACAAGGAAGGGCCCCATACG & & & & \\
\hline PRSV-3' end (10320) & СTCTCATTCTAAGAGGCTCAAATAACACGTG & $\begin{array}{c}68^{\circ} \mathrm{C}\left(-1^{\circ} \mathrm{C} / \text { cycle }\right. \\
\text { for } 15 \text { cycles })\end{array}$ & $53^{\circ} \mathrm{C}(25$ cycles $)$ & 1,286 & PRSV \\
\hline LCV $-50(n t 1)^{c}$ & GAAATCAAACTTTCCTTCG & & & & \\
\hline LCV-25 (nt 483$)^{\mathrm{c}}$ & GGCATCCTGTTAAATCTGCA & $\begin{array}{c}68^{\circ} \mathrm{C}\left(-1^{\circ} \mathrm{C} / \text { cycle }\right. \\
\text { for } 15 \text { cycles })\end{array}$ & $50^{\circ} \mathrm{C}(25$ cycles $)$ & 483 & LCV RNA1 \\
\hline LCV1-F1 (nt263) & GTCACGTTAAGACTAGTGAGGTCTC & & & & \\
\hline LCV1-R4 (nt3062) & TCACCTCTCTCTGCAGTATACATATC & $\begin{array}{c}68^{\circ} \mathrm{C}\left(-1^{\circ} \mathrm{C} / \text { cycle }\right. \\
\text { for } 15 \text { cycles })\end{array}$ & $\begin{array}{l}53^{\circ} \mathrm{C} \text { for } \\
25 \text { cycles })\end{array}$ & 2,799 & LCV RNA1 \\
\hline LCV1-F3 (nt2523) & CGTCGAATATGCAATGAATACTGTGCTAAG & & & & \\
\hline LCV1-R6 (nt4735) & CACTCACGCAGTCCAATAGCAAGTC & $\begin{array}{c}68^{\circ} \mathrm{C}\left(-1^{\circ} \mathrm{C} / \text { cycle }\right. \\
\text { for } 18 \text { cycles })\end{array}$ & $50^{\circ} \mathrm{C}(25$ cycles $)$ & 1,963 & LCV RNA1 \\
\hline LCV1-F5 (nt4486) & GAACTGGGTTATGACGGCAAAGAAGTG & & & & \\
\hline LCV1-R8 (nt7703) & CCACATAGAGATTTATTGTAAGTTTGAGTC & $\begin{array}{c}68^{\circ} \mathrm{C}\left(-1^{\circ} \mathrm{C} / \text { cycle }\right. \\
\text { for } 18 \text { cycles })\end{array}$ & $50^{\circ} \mathrm{C}(25$ cycles $)$ & 3,217 & LCV RNA1 \\
\hline LCV1-F7 (nt7489) & CATACATTGCATGTATGCAAACATGGTGGC & & & & \\
\hline LCV55 (nt8220) & CGGCCTAGTTATTCTATTAACTAGTCTCTC & $\begin{array}{c}65^{\circ} \mathrm{C}\left(-1^{\circ} \mathrm{C} / \text { cycle }\right. \\
\text { for } 15 \text { cycles })\end{array}$ & $50^{\circ} \mathrm{C}(25$ cycles $)$ & 1,102 & LCV RNA1 \\
\hline LCV $5^{\prime}$ end (nt1) & GAAATTTCCACGGTTTCCCCG & & & & \\
\hline LCV-R2 (nt1558) & GGTACCAAAGTCCAACCCTGCCTTAGCTGC & $\begin{array}{c}68^{\circ} \mathrm{C}\left(-1^{\circ} \mathrm{C} / \text { cycle }\right. \\
\text { for } 15 \text { cycles })\end{array}$ & $53^{\circ} \mathrm{C}(25$ cycles $)$ & & LCV RNA2 \\
\hline LCV2-F1 (nt332) & GTGTACGGTGCATACCTCACGATG & & & & \\
\hline LCV2-R4 (nt2598) & GAACATCCAAAAGACACGGCAGATCG & $\begin{array}{c}68^{\circ} \mathrm{C}\left(-1^{\circ} \mathrm{C} / \text { cycle }\right. \\
\text { for } 18 \text { cycles })\end{array}$ & $50^{\circ} \mathrm{C}(25$ cycles $)$ & 2,266 & LCV RNA2 \\
\hline LCV2-F3 (nt2300) & GAAGCCAATTCAAGTGGTAGGGAGTC & & & & \\
\hline LCV2-R6 (nt5789) & CTTACCAGTGGCTTTCAGAATTTCAATGTC & $\begin{array}{c}68^{\circ} \mathrm{C}\left(-1^{\circ} \mathrm{C} / \text { cycle }\right. \\
\text { for } 18 \text { cycles })\end{array}$ & $50^{\circ} \mathrm{C}(25$ cycles $)$ & 3,489 & LCV RNA2 \\
\hline LCV2-F5 (nt5526) & GTTGACGGTGAACCAACTGCTGATG & & & & \\
\hline LCV2-R8 (nt8556) & CGGCCTAGCTATACTACTAACTAGTCG & $\begin{array}{c}68^{\circ} \mathrm{C}\left(-1^{\circ} \mathrm{C} / \text { cycle }\right. \\
\text { for } 15 \text { cycles })\end{array}$ & $53^{\circ} \mathrm{C}(25$ cycles $)$ & 3,030 & LCV RNA2 \\
\hline TYPap-C1a_F (nt1607) & GCTCGTAGAGGGTGACGAAG & & & & \\
\hline TYPap-C1a_R (nt1591) & GAGCCACTGTTCGCAAGTAT & $55^{\circ} \mathrm{C}$ (35 cycles) & & 2,781 & TYLCV-IL \\
\hline TYPap-C2a_F (nt1358) & TGGTTCATTAGAAATGGCCTC & & & & \\
\hline TYPap-C2a_R (nt1396) & GATAACAGAACACAGCCAGAGG & $55^{\circ} \mathrm{C}$ ( 35 cycles $)$ & & 2,781 & TYLCV-IL \\
\hline V1701 (nt 1507) & GGTAGTATGAGGATCCACAGTCTAGGTCT & & & & \\
\hline C515 (nt471) & CTKGGCTTHCTRTAYATRGGCC & $55^{\circ} \mathrm{C}(35$ cycles $)$ & & $\sim 1,700$ & TYLCV \\
\hline $2195-\mathrm{F}$ & TTGATTTTTTGGTCATCCAGAAGT & & & & \\
\hline 3014-R & TCCAATCGACTAATCTGCCATATTA & $52^{\circ} \mathrm{C}$ (35 cycles) & & 816 & $\begin{array}{l}\text { Bemisia } \\
\text { mCOI gene }\end{array}$ \\
\hline
\end{tabular}

a Nucleotide (nt) positions based on sequences of PRSV isolate Mex-VrPO (AY231130), LCV RNA1 isolate California (FJ380118), LCV RNA2 isolate California (FJ380119), and TYLCV-IL isolate P3-T1-3 (KX024639).

${ }^{\mathrm{b}}$ A touchdown PCR employed for each primer sets targeting PRSV and LCV.

${ }^{\mathrm{c}}$ Diagnostic primers for routine detection of PRSV, LCV, and TYLCV. 
transplanted into pots and maintained in a greenhouse, to be used as virus source plants. Fifty seed-propagated and virus-free recipient (test) papaya seedlings were placed near the six symptomatic virusinfected papaya plants and greenhouse whiteflies were allowed feeding access to the source and test plants. After 5 months, test plants were analyzed for the presence of the HTS-detected viruses using virusspecific diagnostic primers (Table 1) as described above. The percent infection as single and mixtures of the various virus species were determined. Adult whiteflies were sampled randomly from test plants, pooled into a vial consisting of 20 individuals, and DNA was isolated using a modified version (Ogbe et al. 2006) of the Dellaporta method (Dellaporta et al. 1983). An aliquot of whitefly total DNA was tested for the presence of each virus. The $B$. tabaci sibling species group haplotype was identified by PCR amplification of an $~ 800 \mathrm{bp}$ fragment of the mitochondrial cytochrome oxidase I (mtCOI) gene (Table 1), according to Frohlich et al. (1999), followed by DNA sequencing of the cloned amplicon, and BLASTn analysis. The nucleic acid extract from each field- and greenhouse-collected leaf sample was subjected to PCR amplification using the mtCOI primers to determine if whitefly DNA was present in the total DNA purified from papaya leaves.

\section{Results}

Disease symptoms, spatial analysis, and negative impacts. Spatial analysis of a four-row block of trees located in the middle of the orchard revealed $51 \%$ disease incidence upon the first visit to the orchard during fall 2014. The symptomatic papaya plants were concentrated at the south end of the block, and a diffuse symptom gradient could be discerned in the direction of the north end of the block, suggesting a pattern of spread reminiscent of an arthropod vector(s).

Symptoms observed on affected plants consisted of severe mosaic, leaf distortion, vein-clearing, yellowing, leaf brittleness, and a combination of the different symptom phenotypes (Fig. 1). The symptoms were distinguishable as two categories termed the PRSV infection-like (Fig. 1A, B, and D) and the yellows type (Fig. 1C) phenotypes. The PRSV infection-like phenotype consisted of a foliar, chlorotic mosaic (Fig. 1A), leaf distortion (Fig. 1A and B), and ringspots on the fruit surface (Fig. 1D). The yellows phenotype was characterized by overall yellowing of leaves, vein-clearing, and leaf brittleness (Fig. 1C). Papaya plants exhibiting the 'yellows' phenotype were often more stunted than those showing characteristic PRSV infection-like symptoms. Based on differences in symptomology among the diseased papaya plants, the presence of multiple virus-like pathogens was suspected.

Analysis of 16 pairs of asymptomatic and adjacent symptomatic papaya trees during fall 2014 indicated that tree height and production of fruits were reduced by 7.5 and $23.8 \%$, respectively, indicating a negative effect of the disease on papaya trees (Supplementary Fig. $\mathrm{S} 2$ ). Based on the collective symptom phenotypes, incidence peaked at $100 \%$ by spring 2015, or 6 months after the initial visit, indicating increased disease spread.

Table 2. Classification and abundance of sequence reads generated by Illumina sequencing from three complementary DNA (cDNA) libraries prepared from asymptomatic (PMcA-H) and symptomatic (PMcA-D1 and PMcA-D2) papaya plants

\begin{tabular}{lrrr}
\hline & \multicolumn{3}{c}{ cDNA library } \\
\cline { 2 - 4 } Illumina reads $^{\mathbf{a}}$ & PMcA-H & PMcA-D1 & PMcA-D2 \\
\hline Total reads & $26,416,962$ & $28,335,783$ & $24,188,709$ \\
Trimmed reads & $26,340,043$ & $28,261,498$ & $24,143,896$ \\
\# Contigs & 63,768 & 61,860 & 54,931 \\
Mapped to PRSV & 217,191 & 583,856 & $1,642,246$ \\
Mapped to LCV RNA1 & 312 & 340 & 399 \\
Mapped to LCV RNA2 & 579 & 630 & 641 \\
Mapped to TYLCV-IL & 153 & 75 & 80 \\
Unmapped reads & $3,478,428$ & $4,435,994$ & $3,231,046$ \\
\hline
\end{tabular}

${ }^{a}$ The Illumina reads generated from each cDNA library were mapped to virus/ viroid database. PRSV = Papaya ringspot virus (genus Potyvirus); LCV = Lettuce chlorosis virus (genus Crinivirus); and TYLCV-IL = Tomato yellow leaf curl virus-Israel (genus Begomovirus).
Detection of viruses by Illumina sequencing. The number of total trimmed $75 \mathrm{nt}$ single end reads produced from the three cDNA libraries ranged from 24 to 28 million. The reads were assembled into 54,931 to 63,768 contigs (Table 2). Annotations and tblastx analyses of these contigs against reference viral genomes in the NCBI database recovered genome sequences of PRSV, LCV, and TYLCV-IL (Table 2). Further analysis of the HTS contigs resulted in nearly complete genome sequence assemblies of PRSV, and the RNA1 and RNA2 component of LCV from all three cDNA libraries (Table 3). In contrast, a combined analysis of reads from the three libraries resulted in assembly of only one 301-nt contig that mapped to the genome of TYLCV-IL (Table 3). The results indicated detection of a mixture of plant RNA and DNA viruses in both symptomatic and asymptomatic papaya plants. PRSV is a well-documented, economically important virus and causal agent of papaya ringspot disease (Fermin et al. 2015). However, this is the first report of papaya plants serving as a host of the whitefly-transmitted crinivirus LCV and the association of the whitefly-transmitted geminivirus, TYLCV-IL in papaya, which has been described in a preliminary report (Alabi et al. 2016). The detection of viral sequences in asymptomatic papaya plants (PMcA-H cDNA library; Table 2) underscores the sensitivity of the HTS technology for profiling viral communities even when present in low titers and/or symptoms are not yet apparent in infected plants.

Validation of Illumina sequencing results. To validate viral detection by Illumina sequencing, the complete genome was separately determined by a second method. The viral genome sequences were obtained by PCR amplification of overlapping DNA fragments using virus-specific primers, based on the respective HTS-derived sequence (Table 1), and Sanger DNA sequencing by primer-walking. The apparently complete genome sequence for PRSV consisted of five overlapping DNA fragments ranging in size from 1,283 to $3,787 \mathrm{bp}$ (Table 1). The apparently full length assembled LCV RNA1 component comprised five overlapping DNA fragments ranging from 483 to 3,217 bp, whereas the LCV RNA2 component was assembled from four overlapping DNA fragments of 556 to 3,489 bp in size (Table 1). The N-terminal extremities of PRSV, LCV RNA1, and LCV RNA2 were confirmed by $5^{\prime}$-RACE, and the $3^{\prime}$-RACE assay was used to determine the C-terminal extremities of LCV RNA1 and RNA2 (Table 1). Finally, the apparently full length TYLCV-IL ssDNA genome sequence was $2,781 \mathrm{bp}$ in size (Table 1). Each Sanger-determined viral genome was $100 \%$ identical at the nt level with the respective HTSderived sequence. The Sanger-determined sequence for each virus was deposited in the GenBank database.

Comparative viral genome analyses: Papaya ringspot virus. The ssRNA PRSV genome sequence, at 10,320 nt as determined by Sanger sequencing, was deposited in GenBank as the isolate PRSV-PTX (accession no. KY271954; Fig. 2A). However, only 79.2, 77.2, and 82.1\% of the genome were recovered from cDNA libraries PMcA-H (asymptomatic plants), PMcA-D1, and PMcA-D2 (symptomatic plants), respectively, when the Illumina platform was implemented (Table 3 ).

The PRSV-PTX 5' untranslated region (UTR) and 3'UTR were 85 and $206 \mathrm{nt}$ in length, respectively (Table 4). As has been reported for previously characterized PRSV strain $\mathrm{P}$ isolates (Noa-Carrazana et al. 2007; Yeh et al. 1992), 10 protein products could be predicted

Table 3. Read lengths and percent (\%) genome coverage for viruses detected via Illumina sequencing of three complementary DNA (cDNA) libraries prepared from asymptomatic (PMcA-H) and symptomatic (PMcA-D1 and PMcA-D2) papaya plants

\begin{tabular}{lccc}
\hline & \multicolumn{3}{c}{ Read length (\% genome coverage) } \\
\cline { 2 - 4 } Viruses detected $^{\mathbf{a}}$ & PMcA-H & PMcA-D1 & PMcA-D2 \\
\hline PRSV & $8,172(79.2 \%)$ & $7,970(77.2 \%)$ & $8,472(82.1 \%)$ \\
LCV RNA1 & $6,075(70.7 \%)$ & $5,536(64.4 \%)$ & $7,548(87.9 \%)$ \\
LCV RNA2 & $7,319(85.5 \%)$ & $5,369(62.8 \%)$ & $7,671(89.7 \%)$ \\
TYLCV-IL & & $301(10.8 \%)$ & \\
\hline
\end{tabular}

${ }^{a} \mathrm{PRSV}=$ Papaya ringspot virus (genus Potyvirus); $\mathrm{LCV}=$ Lettuce chlorosis virus (genus Crinivirus); and TYLCV-IL = Tomato yellow leaf curl virusIsrael (genus Begomovirus). 
based on PRSV-PTX polyprotein (3,342 aa) viral-encoded protease cleavage sites (Fig. 2A). As shown in Figure 2A, the PRSV isolates from the Americas including PRSV-PTX (this study), PRSV-HA (S46722) (Yeh et al. 1992), and PRSV-Mex-VrPO (AY231130) (Noa-Carrazana et al. 2007) are more closely related to each other than to the Asian isolates, PRSV-P-Thai (AY162218), PRSV-W (AY010722), PRSV-CI (AY027810), and PRSV-YK (X97251) (Fig. 2A).

The results of within-species pairwise comparisons of the complete PRSV-PTX genome (96\%), and the polyprotein at the nt $(96 \%)$ and amino acid (aa) (97\%) levels, indicated the isolate was most closely related to PRSV-Mex-VrPO, a severe PRSV strain P isolate (Table 4) reported from Veracruz, Mexico (Noa-Carrazana et al. 2007). Also, the individual protein sequences encoded by PRSV-PTX and the Nand C-terminal UTRs were most identical to the analogous regions of PRSV-Mex-VrPO (Table 4). Interestingly, Veracruz State, Mexico, and the Lower Rio Grande Valley, Texas, study sites share a common proximity with the Gulf of Mexico that has facilitated the exchange of plant materials between the two locales.

Lettuce chlorosis virus. The LCV RNA1 and RNA2 sequences (isolate LCV-PTX) determined herein by Sanger sequencing were 8,592 bp (Fig. 2B; KY271955) and 8,556 bp (Fig. 2C; KY271956) in size, respectively. For this isolate, only 70.7, 64.4, and $87.9 \%$ of the RNA1 genome segment was recovered by Illumina sequencing from cDNA libraries PMcA-H, PMcA-D1, and PMcA-D2, respectively (Table 3). Similarly, for the LCV RNA2, 85.5, 62.8, and $89.7 \%$ were recovered from Illumina-sequenced cDNA libraries PMcA-H, PMcA-D1, and PMcA-D2, respectively (Table 3). By comparison, the recovery of LCV RNA1 was slightly greater than for LCV RNA2. The RNA1 and RNA2 segments of LCV-PTX were identical in sequence to a California LCV isolate (LCV-CA) (Fig. 2B and $\mathrm{C}$ ), which itself is distantly related to other criniviruses (Salem et al. 2009). However, while the RNA2 of LCV-PTX shares $100 \%$ nt identity with LCV-CA, the RNA1 of the two isolates diverged by $1 \%$ at the $\mathrm{N}$-terminal portion of ORF1a (Fig. 2B), owing to amino acid substitutions at different positions in the papain-like protease (P-Pro) domain of the virus (Supplementary Fig. S3).

Tomato yellow leaf curl virus-IL. One begomovirus monopartite genome component of 2,781 nt, identified by BLASTn analysis as TYLCV-IL, was detected by Sanger sequencing from three symptomatic papaya samples (Alabi et al. 2016). By Illumina sequencing, the combined reads from three cDNA libraries produced a single contig comprising $10.8 \%$ of the size expected for the Sanger-sequenced genome identified by BLASTn as TYLCV-IL (Table 3). The pairwise comparison of 12 full-length genome sequences were 99 to $100 \%$ nt identical to each other, shared their maximum nt identities at 98 to $99 \%$ with, and were phylogenetically most closely related to TYLCV-IL from Sinaloa, Mexico (EF523478) (Fig. 3). The sequences for the complete genome sequences have been deposited in GenBank as the accession nos. KX024639-50. Perhaps unexpectedly, the complete genome sequences of the papaya-infecting TYLCV-IL isolates were relatively more diverged (up to $3 \%$ ) from a tomato-infecting isolate of the virus (EF110890) described earlier from Texas (Isakeit et al. 2007). Notably, the papaya isolates lack a 29-bp deletion occurring in the intergenic (nonprotein coding) region between nt coordinates 2,700 and 2,728 of the Sinaloa tomato

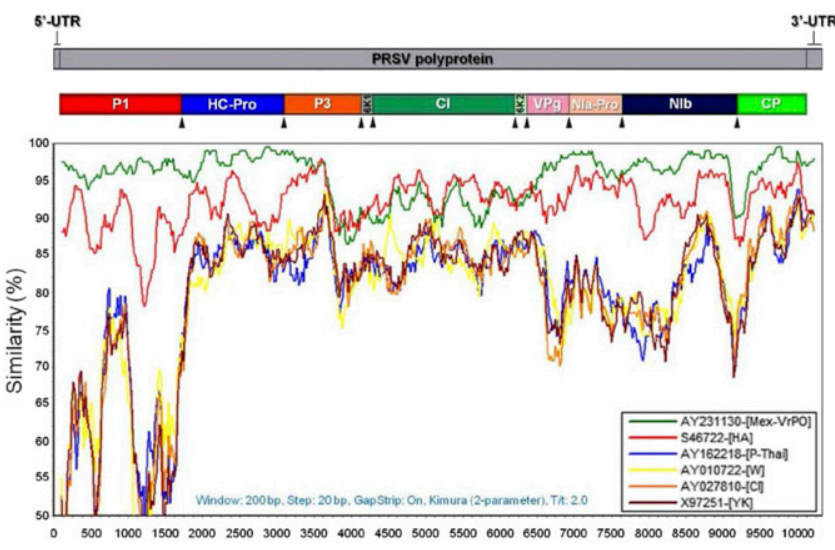

A

Position in virus genome

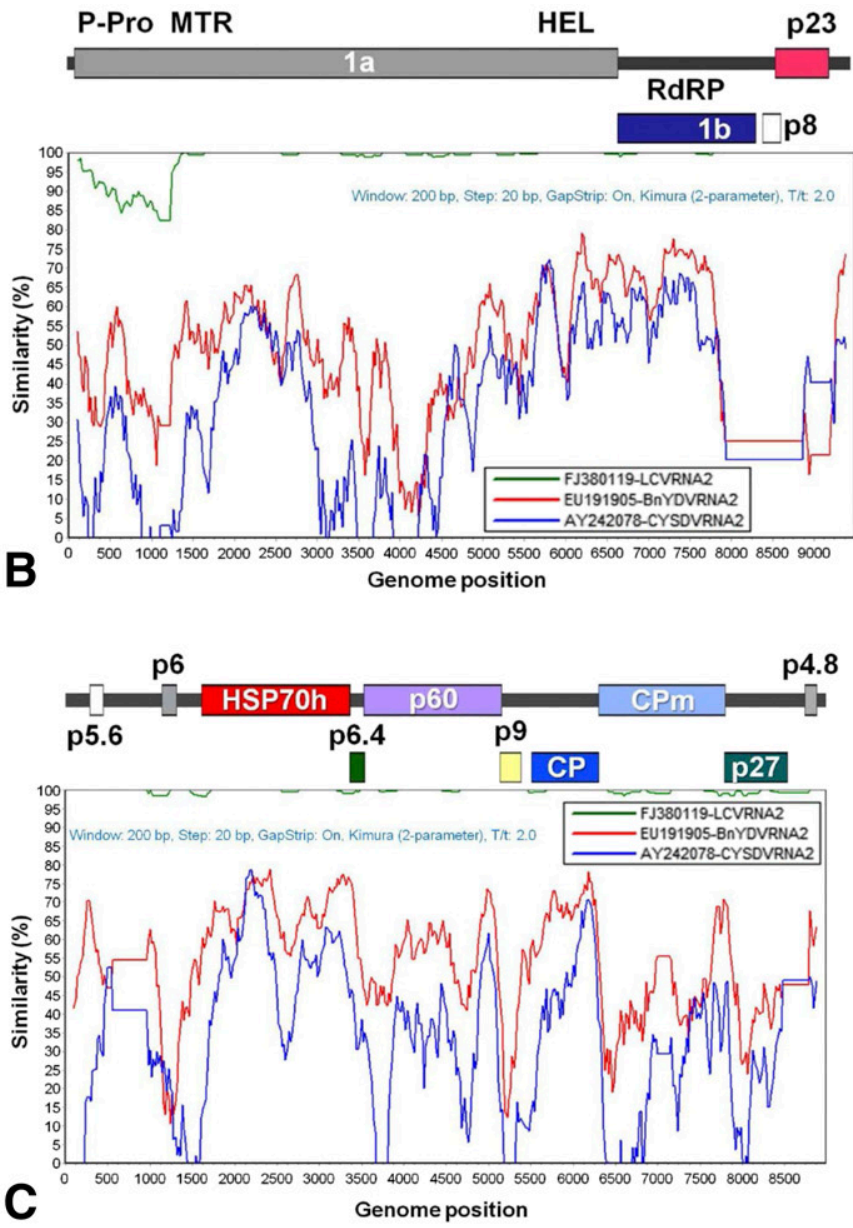

Fig. 2. Sliding-window Simplot graphs showing genome-wide comparisons of isolate PTX of Papaya ringspot virus (PRSV) (A), Lettuce chlorosis virus (LCV) RNA1 (B), and LCV RNA2 (C) with other isolates of the virus. The Simplots were generated using multiple sequence alignments of virus isolates with a window size of $200 \mathrm{nt}$ and a step size of $20 \mathrm{nts}$. Diagrammatic representations of the PRSV and LCV genomes with locations of the encoded proteins from $5^{\prime}$ to $3^{\prime}$ are shown above the graphs. Details of genome organizations of PRSV (Fermin et al. 2015) and LCV (Salem et al. 2009) are available. 
isolate (Supplementary Fig. S4). The discovery of this previously unreported TYLCV-IL strain in Texas suggests that either the papaya isolate has been recently introduced into Texas on plants or by dispersing viruliferous $B$. tabaci whitefly, or that it has been present in the region for some time but undetected.

Single and mixed infections in papaya orchards. Molecular screening of 51 orchard-collected papaya samples by PCR amplification with virus-specific primers (Table 1) designed to detect each of the three viruses discovered by Illumina sequencing, detected PRSV, LCV, and TYLCV-IL in $100 \%$ (51/51), 39.2\% (20/51), and $21.6 \%$ (11/51) of samples (Fig. 4A). Thus, a significantly higher proportion of plants were infected with PRSV (100\% or 51/51) relative to LCV (39.2\% or 20/51) and TYLCV-IL $(21.6 \%$ or $11 / 51)$, both of which had comparable incidence levels $\left(\chi^{2}=69.43\right.$, df $\left.=2, P<0.0001\right)$. The results also revealed the predominance of plants singly infected with PRSV (54.9\%) over infections containing mixtures of different combinations of viruses $(45.1 \%)\left(\chi^{2}=36.68\right.$, df $=3, P<0.0001$; Fig. 4A). Among the 51 samples, LCV and TYLCV-IL were never detected singly infecting papaya plants. Symptoms observed on plants infected with PRSV alone or in a mixed infection of PRSV + TYLCV-IL manifested primarily as the PRSV infection-like phenotype, e.g., mosaic and leaf distortion and leaves that were firm to the touch (Fig. 5A). In contrast, leaves of plants harboring mixed infections consisting of LCV + PRSV, with or without TYLCV-IL, showed partial or complete foliar yellowing, vein-clearing, reduced leaf size, and brittleness (Fig. 5B). Thus, infection of papaya plants by LCV appeared to be a common denominator among plants exhibiting a 'yellows symptom phenotype', and one that points to the possibility for synergistic interactions between LCV and PRSV in the yellows (Fig. 5B) compared to the characteristic PRSV symptom phenotype (Fig. 5A) in papaya plants.

Whitefly-mediated transmission of LCV and TYLCV-IL. Molecular screening by (RT)-PCR of source plants exposed to viruliferous whiteflies during transmission studies resulted in the detection of a mixed infection consisting of PRSV + TYLCV-IL in three of six plants, whereas the rest of the plants (3/6) were positive for infection by all three viruses (data not shown). Following a 5-month exposure of 50 greenhouse-grown recipient papaya plants, propagated from seed, to viruliferous whiteflies, all plants were tested for all three viruses. Results indicated 40\% (20/50) were positive for TYLCV-IL alone, $20 \%$ (10/50) were infected only by LCV, and 14\% (7/50) harbored a mixed LCV + TYLCV-IL, while 26\% (13/50) were negative for both whitefly-transmitted viruses (Fig. 4B; Supplementary Fig.

Table 4. Percent (\%) nucleotide (nt) and amino acid (aa) identities between untranslated regions (UTR), cleaved proteins and complete genome of $P a$ paya ringspot virus isolate PTX (PRSV-PTX) derived in this study (GenBank accession no. KY27195) and corresponding sequences of other PRSV isolates $^{\mathrm{a}}$

\begin{tabular}{|c|c|c|c|c|c|c|c|c|c|c|c|c|c|}
\hline \multirow{2}{*}{$\begin{array}{l}\text { PRSV- } \\
\text { PTX }\end{array}$} & \multirow{2}{*}{$\begin{array}{c}\text { Length } \\
\text { (bp) }\end{array}$} & \multicolumn{2}{|c|}{$\begin{array}{l}\text { Mex- } \\
\text { VrPo }\end{array}$} & \multicolumn{2}{|c|}{ HA } & \multicolumn{2}{|c|}{ W } & \multicolumn{2}{|c|}{$\begin{array}{l}\text { P- } \\
\text { Thai }\end{array}$} & \multicolumn{2}{|c|}{ CI } & \multicolumn{2}{|c|}{ YK } \\
\hline & & nt & aa & nt & aa & nt & aa & nt & aa & nt & aa & nt & aa \\
\hline Genome & 10,320 & 96 & - & 93 & - & 83 & - & 83 & - & 83 & - & 83 & \\
\hline 5’UTR & 85 & 99 & - & 92 & - & 68 & - & 67 & - & 72 & - & 67 & - \\
\hline Polyprotein & 3,342 & 96 & 97 & 93 & 95 & 83 & 91 & 83 & 91 & 83 & 91 & 83 & 91 \\
\hline $\mathrm{P} 1$ & 1,641 & 96 & 96 & 89 & 86 & 71 & 67 & 72 & 67 & 71 & 68 & 71 & 69 \\
\hline HC-Pro & 1,371 & 98 & 99 & 92 & 96 & 86 & 96 & 87 & 96 & 87 & 95 & 87 & 96 \\
\hline P3 & 1,035 & 94 & 94 & 94 & 94 & 87 & 96 & 85 & 94 & 86 & 96 & 87 & 96 \\
\hline $6 \mathrm{~K} 1$ & 156 & 90 & 90 & 91 & 94 & 85 & 96 & 86 & 92 & 86 & 96 & 84 & 90 \\
\hline CI & 1,905 & 92 & 98 & 94 & 98 & 86 & 99 & 86 & 97 & 86 & 98 & 86 & 97 \\
\hline $6 \mathrm{~K} 2$ & 171 & 92 & 93 & 93 & 93 & 87 & 95 & 88 & 95 & 87 & 91 & 88 & 91 \\
\hline VPg & 567 & 96 & 99 & 92 & 95 & 84 & 94 & 84 & 93 & 81 & 93 & 83 & 94 \\
\hline NIa-Pro & 714 & 97 & 99 & 95 & 97 & 82 & 93 & 83 & 94 & 82 & 93 & 82 & 95 \\
\hline $\mathrm{NIb}$ & 1,551 & 97 & 99 & 93 & 97 & 83 & 97 & 82 & 95 & 83 & 96 & 83 & 96 \\
\hline $\mathrm{CP}$ & 918 & 97 & 97 & 93 & 96 & 88 & 94 & 88 & 92 & 88 & 93 & 87 & 92 \\
\hline 3'UTR & 206 & 98 & - & 92 & . & 91 & . & 91 & - & 89 & - & 91 & \\
\hline
\end{tabular}

${ }^{\mathrm{a}}$ GenBank accession numbers of the PRSV isolates used for comparisons are AY231130 (PRSV-Mex-VrPO), S46722 (PRSV-HA), AY010722 (PRSV-W), AY162218 (PRSV-P-Thai), AY027810 (PRSV-CI), and X97251 (PRSV-YK).
S5). Plants tested positive for LCV \pm TYLCV-IL showed systemic yellowing of the foliage but the symptoms were inconsistent across infected plants (data not shown). No discernible symptoms were observed on plants infected with TYLCV-IL.

The whiteflies sampled as cohorts of individuals that were collected randomly from the greenhouse-grown papaya seedlings, also tested positive for LCV and TYLCV-IL. Among the 50 papaya plant and whitefly cohort samples, none tested positive for PRSV (data not shown). Also, when PCR primers that amplify a fragment of the whitefly mtCOI (Frohlich et al. 1999) were used to test total nucleic acids isolated from papaya leaf samples for presence of contaminating whitefly DNA, no PCR product was detectable in any sample, excluding the possibility that LCV and TYLCV-IL detection in plants that were positive for virus presence, was due to whitefly DNA contamination of the leaf samples. Based on PCR amplification of the whitefly mtCOI gene fragment $(\sim 800 \mathrm{bp})$, DNA sequencing, and BLASTn analysis of resultant cloned amplicons, the B. tabaci whitefly associated with virus transmission in the greenhouse was identified as a Q-like biotype (Alabi et al., unpublished data). Thus, this result implicates the $\mathrm{Q}$ biotype of $B$. tabaci as a whitefly vector of LCV and TYLCV-IL to papaya, and as a potential vector of these viruses to other susceptible plant hosts.

\section{Discussion}

This study reports the association of single and/or mixed infections of LCV, PRSV, and TYLCV-IL with a severe virus disease of papaya

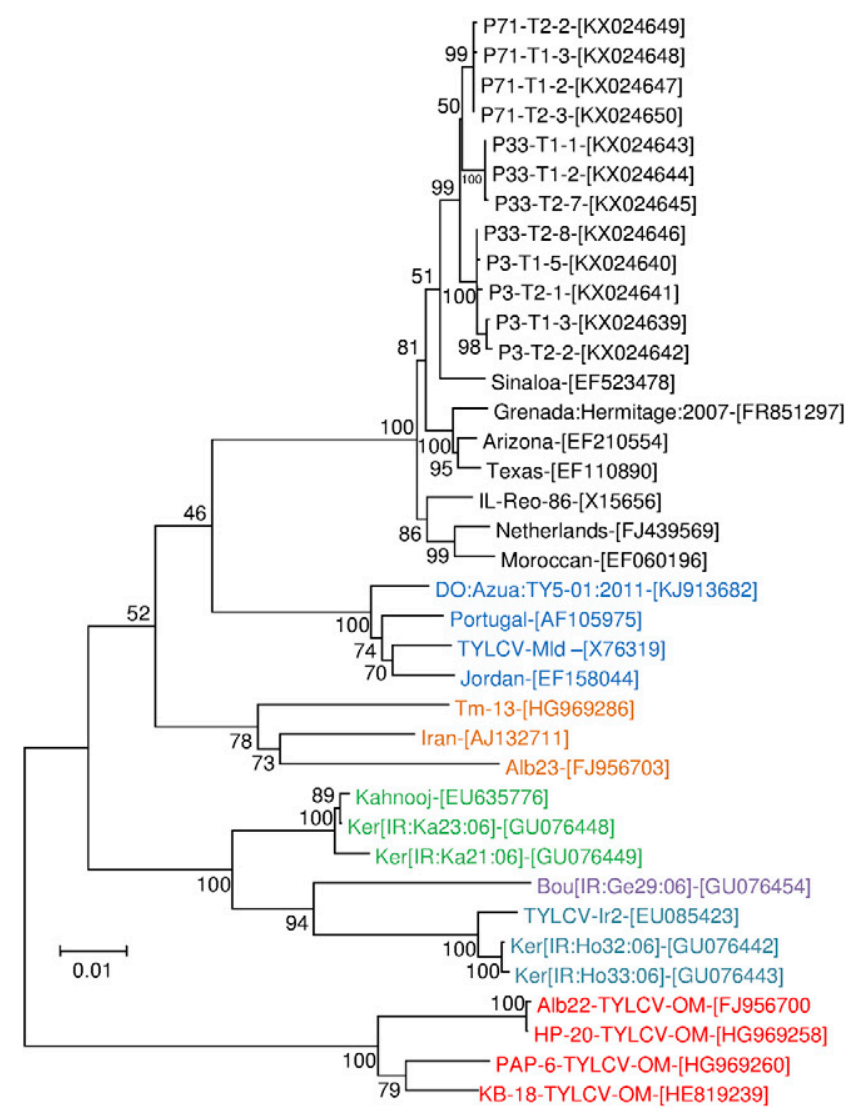

Fig. 3. The unrooted neighbor-joining tree depicting evolutionary relationships among isolates of different Tomato yellow leaf curl virus (TYLCV) strains. The percentage of replicate trees in which the associated virus isolates clustered together in the bootstrap test (1,000 replicates) are shown next to the branches (Felsenstein 1985). The tree is drawn to scale, with branch lengths in the same units as those of the evolutionary distances used to infer the phylogenetic tree. The evolutionary distances were computed using the maximum composite likelihood method (Tamura et al. 2004) and are in the units of the number of base substitutions per site. The analysis was conducted in MEGA7 (Kumar et al. 2016) and involved complete genome sequences of 37 TYLCV isolates. Sequences with GenBank accession nos. KX024639-50 were derived in this study while others were retrieved from the GenBank database. Colored texts denote different strains of the virus. 
in a commercial orchard located in Texas. Whereas papaya is a wellknown host of PRSV, the detection and characterization of LCV and TYLCV-IL isolates associated with papaya extends our knowledge of the natural host range for two widely distributed whiteflytransmitted viruses, known primarily to infect vegetable crops. In addition to being taxonomically distinct, these three viruses differ with respect to morphological and biological properties. Whereas LCV and PRSV each possess a linear positive-sense ssRNA genome encapsidated in a long flexuous particle, the circular positive-sense ssDNA genome of TYLCV-IL is encapsidated in a geminate (twinned) isometric particle. Further, the three viruses also differ in genome size and organization, number of encoded proteins, and by their particular
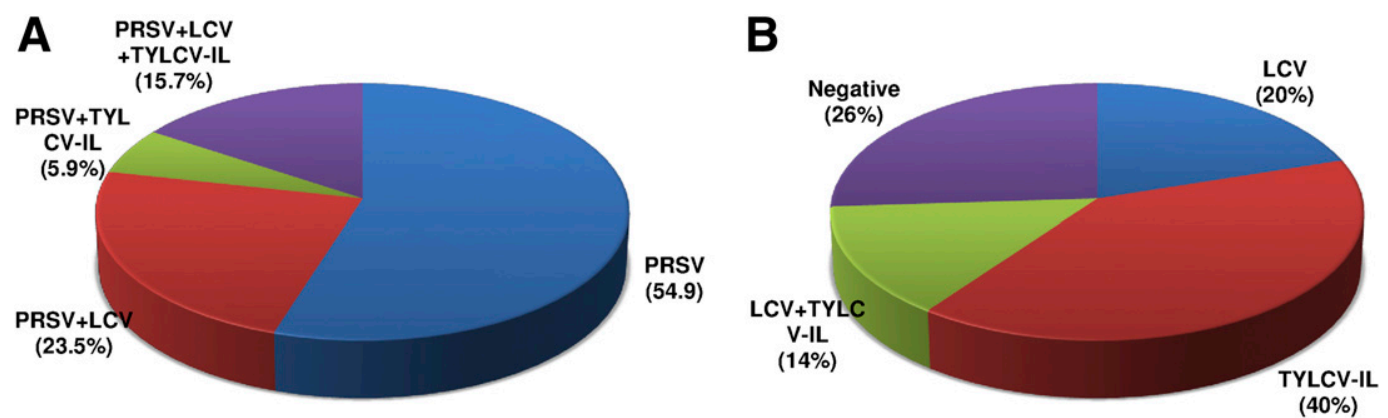

Fig. 4. Relative proportions of single versus mixed infections of Lettuce chlorosis virus (LCV), Papaya ringspot virus (PRSV), and Tomato yellow leaf curl virus-Israel (TYLCV-IL) in papaya plants under field (A) and greenhouse (B) conditions. A total of 51 papaya plants were evaluated for the field assessment while 50 virus-free papaya seedlings were used for the whitefly transmission experiment under greenhouse conditions (B).

A
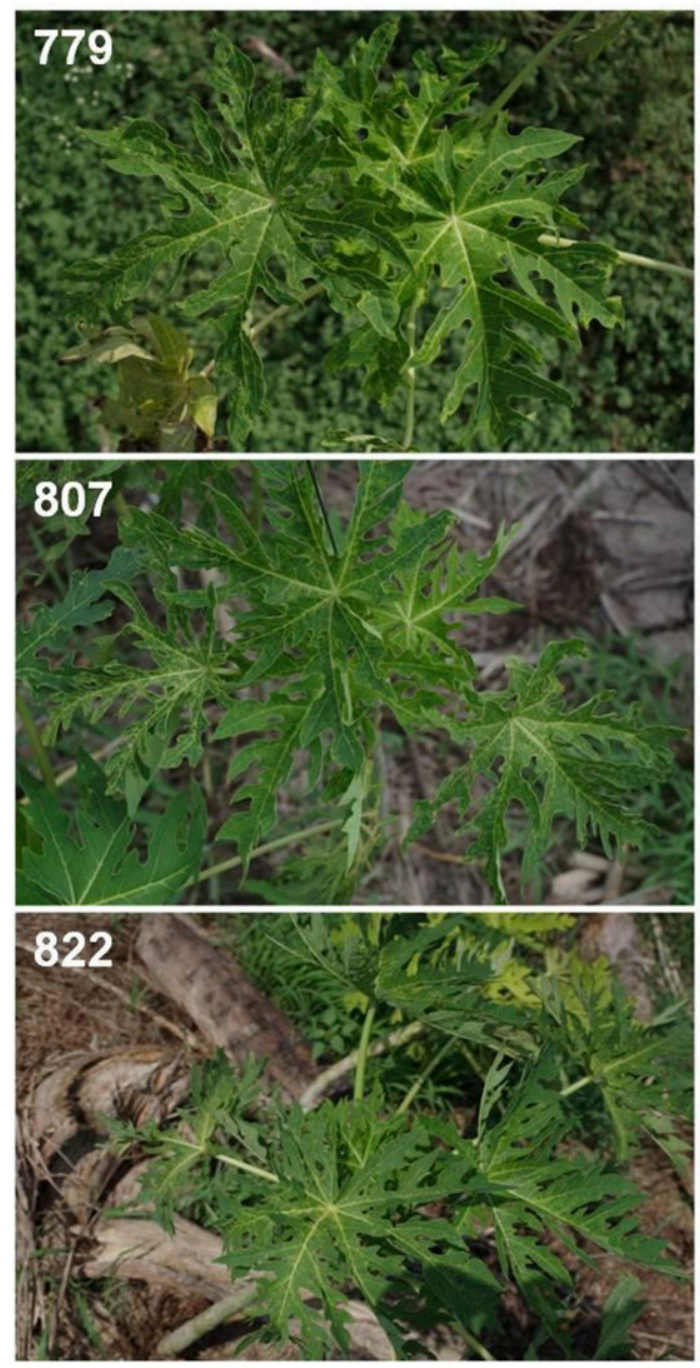

B
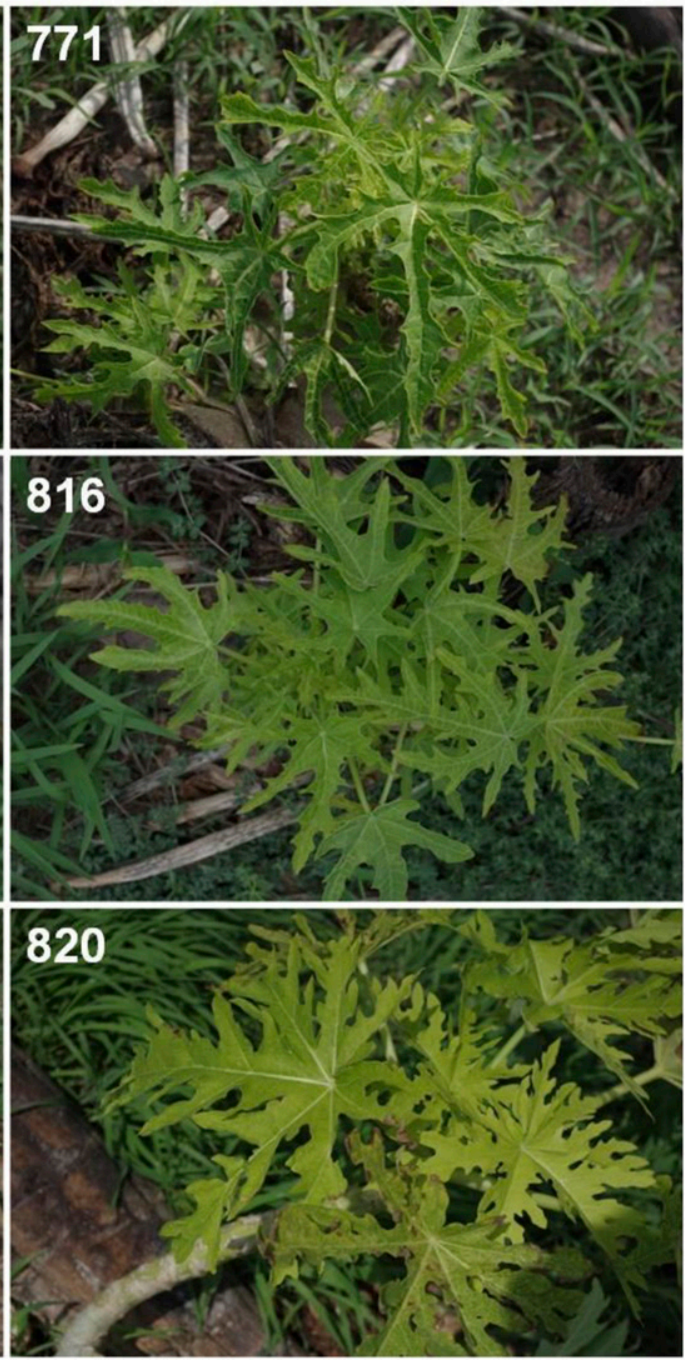

Fig. 5. Expressions of two distinct symptom phenotypes in virus-infected papaya plants under field conditions. The Papaya ringspot virus (PRSV)-like phenotype consisted of mosaic with or without leaf distortion (A) while the yellows phenotype is characterized by foliar yellowing, vein-clearing, and brittleness (B). Plants showing the yellows phenotype consistently harbored mixed infection of Lettuce chlorosis virus (LCV) \pm Tomato yellow leaf curl virus-Israel (TYLCV-IL), whereas those showing the PRSV infection-like phenotype are positive for PRSV \pm TYLCV-IL. The field IDs for each plant are indicated. 
insect vector and transmission characteristics. With respect to protein-coding capacity, the PRSV genome encodes 10 mature proteins produced via polyprotein cleavage by viral-encoded proteases (Fig. 2A) (Yeh and Gonsalves 1985), whereas LCV possesses a bipartite genome whose components are separately encapsidated (Martelli et al. 2011), collectively encoding at least 13 proteins (three on RNA1 and 10 on RNA2) (Fig. 2B and C) (Salem et al. 2009). The relatively smaller monopartite genome of TYLCV-IL on the other hand encodes two virion-sense and four complementary-sense overlapping proteins separated by an intergenic (nonprotein coding) region. In addition, PRSV is horizontally-transmitted by aphids in a nonpersistent manner (Gonsalves 1998) whereas LCV and TYLCV are whitefly-transmitted in semipersistent (Duffus et al. 1996) and persistent (Cohen and Nitzany 1966) manners, respectively. Tomato is the primary host of TYLCV, although its occurrence has been documented in several asymptomatic cultivated and weed plant species (Hamilton et al. 2015 and references therein). In contrast, PRSV infects species spanning several plant families including Amaranthaceae, Caricaceae, Cucurbitaceae, and Fabaceae (Fermin et al. 2015 and references therein) while LCV has a relatively wider host range consisting of cultivated and weed plant species belonging to 13 families (Tzanetakis et al. 2013 and references therein).

In a previous study, papaya was reported as a non-TYLCV host (Dickey et al. 2012), leading to the adoption of continuous use of the papaya banker plant system in reduced-chemical management of B. tabaci in tomato greenhouses (Xiao et al. 2011). Therefore, this first report of TYLCV-IL infection of papaya plants (Alabi et al. 2016 and this study) is significant in that it demonstrates that the $B$. tabaci Q biotype is capable of feeding on papaya plants, and of transmitting the virus between papaya plants. These findings also have broad implications for whitefly vector management in papaya orchards, and in nearby tomato producing areas, both in the field and greenhouse operations. Papaya is a perennial host plant and the whitefly B. tabaci $\mathrm{B}$ and $\mathrm{Q}$ biotypes are considered polyphagous vector species. The subtropical conditions of the southern region of Texas support high whitefly population levels during much of the year, and provide 'green bridge' vegetation for the survival of TYLCV and other damaging viruses in plants, year round. In addition, the location of the papaya orchard near the U.S.-Mexico border puts each country at risk due to the potential for exotic virus introductions. Thus, similar to other perennial (Hammond 1981; Prendeville et al. 2012; Raybould et al. 1999) and wild (Alabi et al. 2008; Tugume et al. 2016) plant species harboring mixed virus infections, papaya can serve as an overwintering and oversummering host to agriculturally relevant virus species.

The increased affordability of HTS technologies is expected to increase the likelihood of virus detection, not only in symptomatic plants, but also of asymptomatic infections. As shown in Table 2, comparatively equal number of Illumina reads were recovered from cDNA libraries PMcA-H (asymptomatic plants), PMcA-D1, and PMcA-D2 (symptomatic plants), respectively, when the Illumina platform was implemented. Furthermore, the genome coverages for each of the three detected viruses were comparatively similar for all three cDNA libraries (Table 3). These results further underscore the versatility of the HTS technology for plant virus detection under low titer conditions (Al Rwahnih et al. 2015) and when symptoms of virus infection may be unapparent in infected plants.

Symptoms observed on plants singly infected by PRSV or harboring PRSV + TYLCV-IL (Fig. 5A) were consistent with those described previously for PRSV (Hamilton et al. 2015), but differed considerably among the plants harboring a mixed PRSV + LCV infection, or a combination of the three viruses (Fig. 5B). Symptoms in papaya plants exhibiting the 'yellows phenotype' were more severe than those observed for singly infected plants, suggesting a possible synergism due to virus-virus interactions in infected papaya plants. Because LCV is the common denominator associated with the two different symptom phenotypes observed in virus-infected papaya plants, it is hypothesized to have a key role in synergism. Similar synergistic outcomes have been documented for coinfections of other crinivirus-potyvirus combinations; including Sweet potato chlorotic stunt virus and Sweet potato feathery mottle virus in sweet potato
(Karyeija et al. 2000), Blackberry yellow vein-associated virus and Blackberry virus $Y$ in blackberry (Susaimuthu et al. 2008), and Lettuce infectious yellows virus with Turnip mosaic viruses in Nicotiana benthamiana (Wang et al. 2009). Future studies are needed to determine if the interaction between LCV and PRSV in mixed-infected papaya plants may alter the titer of either or both viruses and what (if any) role TYLCV-IL may contribute to these interactions.

The results of the whitefly transmission experiment showed that both LCV and TYLCV are transmissible between papaya plants, and provide support for the plausible outbreak caused by both viruses in the papaya orchard. However, while LCV incidence was greater $(39.2 \%)$ than TYLCV-IL (21.6\%) under field conditions (Fig. 4A), the converse was true in greenhouse-grown plants (Fig. 4B). This may possibly be explained by the suspected over-seasoning of LCV in resident weeds within the orchard or adjoining fields, whereas TYLCV-IL inoculum sources within or outside the orchard are thought to be fewer at the study location. Conversely, high incidence of TYLCV-IL (54\%) relative to LCV (34\%) in the greenhousemaintained papaya plants (Fig. 4B) could possibly have occurred because there were more TYLCV-IL (6/6) than LCV (3/6) source plants. It is also possible that TYLCV-IL is more efficiently acquired and transmitted by the Q biotype than LCV. Also, TYLCV-IL is persistent and transmitted for life by the whitefly B. tabaci (Rubinstein and Czosnek 1997; Sánchez-Campos et al. 2016), while LCV is noncirculative, and lost from the vector within days post-acquisition (Duffus et al. 1996), and so must be ingested and acquired for each round of inoculation that leads to transmission. How these different transmission modes may influence virus incidence and spread in papaya plants remains to be determined.

The papaya-associated PRSV and TYLCV-IL isolates each have genome sequence features (Figs. 2 and 3) that differ from analogous isolates reported previously in southern Texas, suggesting the possibility that they are both recent introductions. For example, PRSVPTX is most closely related to PRSV-Mex-VrPO (Fig. 2A and Table 4), a severe isolate of PRSV-P reported from the State of Veracruz, Mexico (Noa-Carrazana et al. 2007). And the TYLCV-IL genome sequences from papaya plants most resemble an isolate from Sinaloa, Mexico (EF523478), when compared with a previously reported TYLCV-IL from Texas (Isakeit et al. 2007). Once introduced, the viruses spread to papaya owing to the nearly year-round abundance of whitefly vector(s). However, the limited availability of LCV sequences available in databases makes it difficult to speculate on virus origin or possible route of entry into the Texas papaya orchard.

In conclusion, the finding herein, together with a recent report (Alabi et al. 2016), expands the already wide host range of LCV (Duffus et al. 1996) and TYLCV-IL (Díaz-Pendón et al. 2010) to include papaya. The perennial nature of papaya presents challenges for management of TYLCV-IL and LCV in annual crop hosts, because papaya can serve as an over-seasoning reservoir for both of these viruses. While the evidence points to the possibility of synergism between LCV and PRSV that results in more than additive symptoms in papaya, studies are needed to characterize the respective viral and host factors involved.

\section{Acknowledgments}

The authors are grateful to Mr. Nathaniel M. Westrick (Department of Plant Pathology, University of California, Davis) and Ms. Regina Hernandez (Texas A\&M University, College Station) for technical help. We are also grateful to anonymous reviewers for their constructive comments and suggestions.

\section{Literature Cited}

Al Rwahnih, M., Alabi, O. J., Westrick, N., Golino, D., and Rowhani, A. 2016. Description of a novel monopartite geminivirus and its defective subviral sequence in grapevine. Phytopathology 107:240-251.

Al Rwahnih, M., Daubert, S., Golino, D., Islas, C., and Rowhani, A. 2015 Comparison of next-generation sequencing versus biological indexing for the optimal detection of viral pathogens in grapevine. Phytopathology 105:758-763.

Alabi, O. J., Al Rwahnih, M., Idris, A. M., Gregg, L., Kmieciak, E., Sétamou, M., and Jifon, J. L. 2016. First report of papaya (Carica papaya) naturally infected with the introduced Tomato yellow leaf curl virus-Israel. Plant Dis. 100:1959.

Alabi, O. J., Ogbe, F. O., Bandyopadhyay, R., Kumar, P. L., Dixon, A. G. O., Hughes, J., and Naidu, R. A. 2008. Alternate hosts of African cassava 
mosaic virus and East African mosaic Cameron virus in Nigeria. Arch. Virol. 153:1743-1747.

Bayot, R. G., Villegas, V. N., Magdalita, P. M., Jovellana, M. D., Espino, T. M., and Exconde, S. B. 1990. Seed transmissibility of Papaya ringspot virus. Philipp. J. Crop Sci. 15:107-111.

Brown, J. K. 2010. Phylogenetic biology of the Bemisia tabaci sibling species group. Pages 31-67 in: Bemisia: Bionomics and Management of a Global Pest. P. A. Stansly and S. E. Naranjo, eds. Springer, Dordrecht, The Netherlands.

Cohen, S., and Nitzany, F. E. 1966. Transmission and host range of Tomato yellow leaf curl virus. Phytopathology 56:1127-1131.

Dellaporta, S. L., Woods, J., and Hicks, J. B. 1983. A plant DNA mini-preparation: version II. Plant Mol. Biol. Report. 1:19-21.

Díaz-Pendón, J. A., Cañizares, M. C., Moriones, E., Bejarano, E. R., Czosnek, H., and Navas-Castillo, J. 2010. Tomato yellow leaf curl viruses: ménage à trois between the virus complex, the plant and the whitefly vector. Mol. Plant Pathol. 11:441-450.

Dickey, A. M., Osborne, L. S., and Mckenzie, C. L. 2012. Papaya (Carica papaya, Brassicales: Caricaceae) is not a host plant of Tomato yellow leaf curl virus (TYLCV; family Geminiviridae, genus Begomovirus). Fla. Entomol. 95:211-213.

Duffus, J. E., Liu, H. Y., Wisler, G. C., and Li, R. 1996. Lettuce chlorosis virus - a new whitefly-transmitted closterovirus. Eur. J. Plant Pathol. 102:591-596.

Edgar, R. C. 2004. MUSCLE: multiple sequence alignment with high accuracy and high throughput. Nucleic Acids Res. 32:1792-1797.

FAOSTAT. 2016. Food and Agriculture Organization (FAO) of the United Nations, Rome. Available at: http://www.fao.org/faostat/en/\#data/QC (accessed 04 January 2017; verified 24 Jan. 2017).

Felsenstein, J. 1985. Confidence limits on phylogenies: An approach using the bootstrap. Evolution 39:783-791.

Fermin, G., and Gonsalves, D. 2003. Papaya: Engineering resistance against Papaya ringspot virus by native, chimeric and synthetic transgenes. Pages 497-518 in: Virus and Virus-like Diseases of Major Crops in Developing Countries. G. Loebenstein and G. Thottapilly, eds. Kluwer Academic Publishers, Dordrecht, The Netherlands.

Fermin, G., Randle, M., and Tennant, P. 2015. Papaya Ringspot. Pages 144-161 in: Virus Diseases of Tropical and Subtropical Crops. P. Tennant and G. Fermin, eds. CAB International, Wallingford, U.K.

Frohlich, D. R., Torres-Jerez, I. I., Bedford, I. D., Markham, P. G., and Brown, J. K. 1999. A phylogeographic analysis of the Bemisia tabaci species complex based on mitochodrial DNA markers. Mol. Ecol. 8:1683-1691.

Fuentes, G., and Santamaria, J. M. 2014. Papaya (Carica papaya L.): Origin, domestication and production. Pages 3-15 in: Genetics and Genomics of Papaya. R. Ming and P. H. Moore, eds. Springer Science and Business Media, New York.

Gonsalves, D. 1998. Control of Papaya ringspot virus in papaya: A case study. Annu. Rev. Phytopathol. 36:415-437.

Hall, T. A. 1999. BioEdit: a user-friendly biological sequence alignment editor and analysis program for Windows 95/98/NT. Nucl. Acids Symp. Ser. 41:95-98.

Hamilton, C. L., Mazumdar-Leighton, S., Amarakoon, I., and Roye, M. 2015. Tomato yellow leaf curl. Pages 177-188 in: Virus Diseases of Tropical and Subtropical Crops. P. Tennant and G. Fermin, eds. CAB International, Wallingford, U.K.

Hammond, J. 1981. Viruses occurring in Plantago species in England. Plant Pathol. 30:237-243.

Idris, A. M., and Brown, J. K. 1998. Sinaloa tomato leaf curl geminivirus: biological and molecular evidence for a new subgroup III virus. Phytopathol. 88:648-657.

Isakeit, T., Idris, A. M., Sunter, G., Black, M. C., and Brown, J. K. 2007. Tomato yellow leaf curl virus in tomato in Texas, originating from transplant facilities. Plant Dis. 91:466.

Kalleshwaraswamy, C. M., and Krishna Kumar, N. K. 2008. Transmission efficiency of Papaya ringspot virus by three aphid species. Phytopathology 98:541-546.

Karyeija, R. F., Kreuze, J. F., Gibson, R. W., and Valkonen, J. P. T. 2000. Synergistic interactions of a potyvirus and a phloem-limited crinivirus in sweetpotato plants. Virology 269:26-36.

Kumar, S., Stecher, G., and Tamura, K. 2016. MEGA7: Molecular Evolutionary Genetics Analysis version 7.0 for bigger datasets. Mol. Biol. Evol. 33:1870-1874.
Lole, K. S., Bollinger, R. C., Paranjape, R. S., Gadkari, D., Kulkarni, S. S., Novak, N. G., Ingersoll, R., Sheppard, H. W., and Ray, S. C. 1999. Full-length Human immunodeficiency virus type 1 genomes from subtype $\mathrm{C}$-infected seroconverters in India, with evidence of intersubtype recombination. J. Virol. 73:152-160.

Martelli, G. P., Agranovsky, A. A., Bar-Joseph, M., Boscia, D., Candresse, T. Coutts, R. H. A., Dolja, V. V., Hu, J. S., Jelkman, W., Karasev, A. V., Martin, R. R., Minafra, A., Namba, S., and Vetten, H. J. 2011. Family Closteroviridae. Pages 987-1001 in: Virus Taxonomy: Ninth Report of the International Committee on Taxonomy of Viruses. A. King, M. J. Adams, E. B. Carstens, and E. J. Lefkowitz, eds. Elsevier-Academic Press, Amsterdam, The Netherlands.

McWilliam, H., Li, W., Uludag, M., Squizzato, S., Park, Y. M., Buso, N., Cowley, A. P., and Lopez, R. 2013. Analysis tool web services from the EMBL-EBI. Nucleic Acids Res. 41:W597-W600.

Noa-Carrazana, J. C., González-de-León, D., and Silva-Rosales, L. 2007. Molecular characterization of a severe isolate of Papaya ringspot virus in Mexico and its relationship with other isolates. Virus Genes 35:109-117.

Ogbe, F. O., Dixon, A. G. O., Hughes, J. d'A., Alabi, O. J., and Okechukwu, R. 2006. Status of cassava begomoviruses and their new natural hosts in Nigeria. Plant Dis. 90:548-553.

Prendeville, H. R., Ye, X., Morris, T. J., and Pilson, D. 2012. Virus infections in wild plant populations are both frequent and often unapparent. Am. J. Bot. 99:1033-1042.

Purcifull, D., Edwardson, J., Hiebert, E., and Gonsalves, D. 1984. Papaya ringspot virus. CMI/AAB Descriptions of Plant Viruses, No. 292. (No. 84 Revised July 1984), Kew, Surrey, U.K

Raybould, A. F., Maskell, I. C., Edwards, M. I., Cooper, J. I., and Gray, A. J. 1999. The prevalence and spatial distribution of viruses in natural populations of Brassica oleraceae. New Phytol. 141:265-275.

Rubinstein, G., and Czosnek, H. 1997. Long-term association of Tomato yellow leaf curl virus with its whitefly vector Bemisia tabaci: Effect on the insect transmission capacity, longevity and fecundity. J. Gen. Virol. 78:2683-2689.

Salem, N. M., Chen, A. Y. S., Tzanetakis, I. E., Mongkolsiriwattana, C., and Ng, J. C. K. 2009. Further complexity of the genus Crinivirus revealed by the complete genome sequence of Lettuce chlorosis virus (LCV) and the similar temporal expression of LCV genomic RNAs 1 and 2. Virology 390:45-55.

Sánchez-Campos, S., Rodríguez-Negrete, E. A., Cruzado, L., Grande-Pérez, A. Bejarano, E. R., Navas-Castillo, J., and Moriones, E. 2016. Tomato yellow leaf curl virus: No evidence for replication in the insect vector Bemisia tabaci. Sci. Rep. 6:30942.

SAS Institute. 2008. Base SAS Procedures Guide Version 9. SAS Institute, Cary, NC

Susaimuthu, J., Tzanetakis, I. E., Gergerich, R. C., Kim, K. S., and Martin, R. R. 2008. Viral interactions lead to decline of blackberry plants. Plant Dis. 92: 1288-1292.

Tamura, K., Nei, M., and Kumar, S. 2004. Prospects for inferring very large phylogenies by using the neighbor-joining method. Proc. Natl. Acad. Sci. USA 101:11030-11035.

Tugume, A. K., Mukasa, S. B., and Valkonen, J. P. T. 2016. Mixed infections of four viruses, the incidence and phylogenetic relationships of Sweet potato chlorotic fleck virus (Betaflexiviridae) isolates in wild species and sweetpotatoes in Uganda and evidence of distinct isolates in East Africa. PLoS ONE 11:e0167769.

Tzanetakis, I. E., Martin, R. R., and Wintermantel, W. M. 2013. Epidemiology of criniviruses: an emerging problem in world agriculture. Front. Microbiol. 4:119.

Wang, J., Turina, M., Medina, V., and Falk, B. W. 2009. Synergistic interaction between the Potyvirus, Turnip mosaic virus and the Crinivirus, Lettuce infectious yellows virus in plants protoplasts. Virus Res. 144:163-170.

Xiao, Y., Chen, J., Cantliffe, D., Mckenzie, C., Houben, K., and Osborne, L. S 2011. Establishment of papaya banker plant system for parasitoid, Encarsia sophia (Hymenoptera: Aphilinidae) against Bemisia tabaci (Hemiptera: Aleyrodidae) in greenhouse tomato production. Biol. Control 58:239-247.

Yeh, S., Jan, F., Chiang, C., Doong, T., Chen, M., Chung, P., and Bau, H. 1992 Complete nucleotide sequence genetic organization of Papaya ringspot virus RNA. J. Gen. Virol. 73:2531-2541.

Yeh, S. D., and Gonsalves, D. 1985. Translation of Papaya ringspot virus RNA in vitro: detection of possible polyprotein that is processed for capsid protein, cylindrical-inclusion protein, and amorphous-inclusion protein. Virology 143 260-271. 